\title{
IRON INTAKE AMONG ADOLESCENT GIRLS BASED ON FAMILY SOCIO-ECONOMIC, FREQUENT HIGH-IRON FOODS CONSUMED AND KNOWLEDGE ABOUT ANEMIA IN PANDEGLANG DISTRICT
}

\author{
Galih Kusuma Aji ${ }^{*}$, Noer Laily ${ }^{1}$, Ida Susanti ${ }^{1}$ \\ ${ }^{1}$ Center for Agro-industrial Technology, Agency for the Assessment and Application of Technology \\ *E-mail: galih.kusuma@bppt.go.id
}

\begin{abstract}
Anemia is a condition with abnormalities in the red blood cells where lack of iron intake was postulated to be the main factor causing anemia. Research on iron intake, therefore, in adolescent girls is essential, specifically in high anemia prevalence area. This study aimed to examine the effect of family socio-economic factors, anemia comprehension, and ten-highest iron foods consumed on iron intake. Observational study with cross sectional design was performed, applying iron consumption as dependent variable and parents' education, employment, income and expenditure, along with ten-highest high-iron foods consumed and knowledge about anemia as independent variables. Iron intake was collected using 3 x 24-hours food recall, and ten-highest iron-rich foods consumed was obtained with 2 x food frequency questionnaire. Family socio-economic factors (education, employment, income and expenditure) and knowledge on anemia were assessed using standard questionnaire with closed-ended interview question. The study highlighted that the average iron intake was $8.11 \pm 2.94 \mathrm{mg} /$ day (ranging from 3.01 to $20.43 \mathrm{mg} /$ day). Obtained data showed that the occupation of father played a role in the iron intake difference $(6.20 \pm 1.72 \mathrm{vs} 8.40 \pm 2.99 \mathrm{mg} / \mathrm{day}$ for formal and informal, $\mathrm{p}<0.05)$. However, no differences were found between iron intake and education of fathers and mothers, maternal occupation, income, and expenses. Ten-highest iron-rich foods consumed did not significantly correlate to the amount of iron consumption $(\mathrm{p}>0.05)$. Moreover, this study in adolescent girls found that there was a negative correlation between knowledge about anemia and iron intake $(r=-0.259, \mathrm{p}<0.05)$. In conclusion, respondents consumed around $8 \mathrm{mg}$ of iron, in average, lower than Recommended Dietary Allowance. Less amount of iron intake might be caused by scarce of high-iron sources consumption.
\end{abstract}

Keywords: iron intake, socio-economic, high-iron source, anemia knowledge

\section{INTRODUCTION}

Anemia is a condition with abnormalities in the blood chemistry such as decreased of hemoglobin level, hematocrit and red blood cells (Handelman \& Levin, 2008; Johnson-Wimbley \& Graham, 2011). Globally, almost 2.3 billion people suffered from anemia, of which were women and children, causing anemia as a serious health problem (United Nations Sub-Committee on Nutrition (ACC/SCN), 2000). Specifically, in Indonesia anemia prevalence was around $21 \%$ in 2013 for people with age more than 1 years old. However, anemia prevalence showed a higher prevalence in women compared to men $(23.9 \%$ vs $18.4 \%$, respectively) (Indonesian Ministry of Health, 2013). More specific to Banten province, anemia prevalence was recorded around 57\% among reproductive women, showing a higher prevalence than national frequency (Prihatini, et al., 2009). Correlating anemia to health, it would affect several outcomes in people, which are reducing productivity, increasing death risk of mother and children, delaying growth and development on children, as well as increasing risk of infection diseases when in moderate level (Lopez, et al., 2016). Low intake of iron sources is responsible for being the main factor causing anemia (Permaesih \& Herman, 2005). Thus, research to study the effect of socio-economic factors, eating habit of iron-foods and knowledge about anemia on iron consumption in adolescent women, particularly, in higher prevalence district of anemia is necessary to be performed.

Anemia prevalence in girls was higher compared to boys, showing a number of $23,90 \%$ and $18.4 \%$, respectively in 2013 (Indonesian Ministry of Health, 2013). More specific to adolescent girls, the prevalence was around 
$57,1 \%$ for aged $10-18$ years old and $39.5 \%$ for aged 19-45 years old in 2012 (Badan Penelitian dan Pengembangan Kesehatan RI, 2012). One of the main causing factor for anemia is low of iron intake (Permaesih \& Herman, 2005). Literatures reported that the intake of iron in female adolescent was vary, consuming 18,3+30,43 mg/day (Kirana, 2011), $11,3 \pm 1,75 \mathrm{mg} /$ day (Cendani \& Murbawani, 2011), and $10.4 \pm 4.02 \mathrm{mg} /$ day (Adhisti \& Puruhita, 2011). However, the reported consumption were not sufficient when compared to recommendations of Ministry of Health of Indonesia, which instructs iron recommended dietary intake (RDI) for girls aged 13-18 years is $26 \mathrm{mg}$ /day (Indonesia Health Ministry Policy number 75 year 2013). The lack of iron intake from the recommendation might be influenced by family socio-economic factors. The nutrient intake for iron was influenced by socioeconomic family, such as education and parents' income (Bharati, et al., 2004; Bhargava, et al., 2001; Galobardes, et al., 2001; Hulshof, et al., 2003; Rahayu \& Dieny, 2012).

In the Netherland, women with low socioeconomic status showed a lower intake of iron $(10.1 \mathrm{mg} / \mathrm{day})$, contrasted to superior socioeconomic status, $10.8 \mathrm{mg} /$ day (Hulshof et al., 2003). Another study in India found that people with low socio-economic status consumed $20 \%$ less of iron resources compared to higher socioeconomic status (Bharati, et al., 2004). In addition, a smaller income also contributed to the selection of foods, which mainly comes from plants sources, effecting on anemia due to lower iron bioavailability (Collings, et al., 2013; Prihatini, et al., 2009; Tatala, et al., 1998). In vitro study to investigate the bioavailability of plant foods showed that legumes resulted around 25\% iron $(1.51 \mathrm{mg} / 100 \mathrm{~g}$ dry basis(db.)), vegetables $10.0 \%$ $(5.6 \mathrm{mg} / 100 \mathrm{~g} \mathrm{db}$.), and if combined together in a menu, such as cereal with legume and vegetables, it corresponded to its bioavailability, ranging from $0.9 \%$ to $7.5 \%(0.31-1.17 \mathrm{mg} / 100 \mathrm{~g} \mathrm{db}$.) (Tatala et al., 1998). Thus, it is important to study the iron intake and possibly frequent high-iron sources ingested.

In addition to socio-economic factors and iron sources that influenced iron intake, knowledge about anemia also might be a determinant in this health problem. The understanding about anemia in people had been researched by many researchers, one of the studies found that around $40 \%$ of respondents had a good knowledge about anemia, another $40 \%$ showed a satisfactory result and the others (20\%) achieved in less level (Soraya, 2013). Other studies also highlighted that knowledge about anemia with a good result was noted at 36.8\% (Puspitaningrum \& Fratika, 2014), 39.1\% (Nora, 2012), and 38.8\% (Prapitasari, 2013). Knowledge about anemia conveyed a significant influence to consume iron supplementation tablet in pregnant women (Nora, 2012; Puspitaningrum \& Fratika, 2014). It highly motivates respondent to consume more iron to prevent anemia, which causes a side-effect to mother and fetus. However, the effect of knowledge about anemia on iron intake has not been fully studied in adolescent girls.

From all of the mentioned explanations, the effect of socio-economic and anemia knowledge on iron intake, generally had been studied. Thus, study focuses on iron intake in adolescent girls from districts with higher prevalence of anemia is very important. This study examined the effect of family socio-economic factors on iron intake in Pandeglang district, known for its high prevalence of anemia. Moreover, this study also explored the relation of knowledge about anemia to iron consumption. In addition, frequently high-iron sources consumed was investigated to study its correlation to iron intake.

\section{METHODS}

This observational research was commenced using a cross-sectional design. This research was performed in the last quarter of 2018. Respondent information (name, age, and sibling), nutritional status, parent's education, employment, and family income as well as food intake and knowledge about anemia were collected during the study. Independent variables in this study were parent's education, employment, income and expenditure, along with ten-highest high-iron foods consumed and anemia comprehension. While, the dependent variable was iron consumption. Prior to study, an ethical clearance from medicine faculty university of Indonesia was obtained with approval number 1028/UN2.F1/Etik/2018. 
Two high schools in Pandeglang district were selected for this study, which were State Islamic Senior High School (MAN) 3 and State Senior High School (SMA) 17 Pandeglang. Purposive consecutive sampling was performed, selecting 65 adolescent girls from 125 girl students. All of the 65 respondents had been fitted the inclusion criteria, which were healthy, age between 15 and 18 years old, body mass index (BMI) for age score in between \pm 2 standard deviation (SD), and neither performing a special diet nor heavy exercises, doing sports not more than five hours a week of moderate exercise or two and a half hours of more intense activity (Piercy, et al., 2018). All respondents, then, signed the informed consent after receiving a full explanation regarding the study. In addition, parent's approval also obtained prior to the study. Due to exclusion criteria, which were resignation from the study, hospitalized, and absent during data collection. Only sixtyone respondents were used for statistical analysis because four respondents were absent during the sampling days.

Three days of 24-hours food recall, performed in non-consecutive days; two days on the weekday, and one day on the weekend (Sunday), to measure nutrients intake, including energy, carbohydrate, protein, fat, and iron, were executed. Nutrients intake was calculated using Nutrisurvey ${ }^{\circledR}$ with Indonesian foods databases. After that, it was compared to the RDI and multiplied with $100 \%$ to calculate the daily percentage of nutrients intake per day.

Food frequency questionnaire (FFQ) was applied for two times with 2 months differ, to measure the frequent of ten-highest iron sources consumed. To calculate the score, eight-scale of FFQ was used, which were never (0), $1 \mathrm{x} /$ month (1), 2-3x/month (2), 1-2x/week (3), 3-4x/week (4), 5 -6x/week (5), $1 \mathrm{x} /$ day (6), and $\geq 1 \mathrm{x} /$ day (7). After that, food score was measured by multiplied the actual score of iron sources with iron content for each source then divided with the highest score (7). Ten-highest iron sources were selected. Finally, to divide into two parameters, we used mean if the data were normally distributed, or median if data were not normally distributed. Calculated score were categorized into not frequent if less than mean or median and frequent if the score was more than equal to mean or median.

Socio-economic data were obtained from direct interview with respondents, except family expenses which gained from respondent's parent by requesting respondents to ask their parent directly. Education was divided into greater than or equal 9 years and less than 9 years. Working status for father was distributed into formal and informal, where formal refers to working in government institutions and big companies with job security and paid monthly as well as paying taxes, meanwhile informal means selfemployed workers, and workers who get paid at small business with no job security and pay no taxes (Bird \& Manning, 2002; Perkins, et al., 2001). Mother working status was allocated into working and no working. Parent's income was calculated by adding mother income, if mother were gained money, to father income. Then, based on Pandeglang income per capita, it was categorized into $<1.5$ million Indonesian Rupiah and $\geq 1.5$ million Indonesian Rupiah. Lastly, family spending was divided into two categories, which were $<1.5$ million Indonesian Rupiah and $\geq 1.5$ million Indonesian Rupiah.

A standard questionnaire with some modification in this study was used (Soraya, 2013). Twenty questions were asked to measure the knowledge about anemia, which was the definition, type and caused of anemia as well as its effects on health. In this study, answer was scored as 1 if the answer was correct and 0 if incorrect. Knowledge about anemia, then, was scored according to mathematical formula, which was total score of right answers divided by total score (20) and multiplied with 100 (Soraya, 2013).

Descriptive analysis was performed for univariate data such as age, BMI/age z-score, iron intake, and \% RDI. In addition, respondent's frequency was presented based on age, nutrition status, snacking habits, parents' education, occupation, income, and spending category. Due to iron intake data were not normally distributed, bivariate analysis between iron intake and parent's education, occupation, income, as well as spending was accomplished using Mann Whitney (Dahlan, 2011). In addition, Spearman rank test was used for analyzing the correlation between iron intake 
and the ten-highest iron sources ingested as well as knowledge about anemia. P-values of $<0.05$ were considered significant. All results are presented as mean \pm standard deviation (SD). Ethical clearance from Faculty of Medicine, Universitas Indonesia was obtained with approval number 1028/UN2. F1/Etik/2018.

\section{RESULTS AND DISCUSSION}

Sixty-one respondent was attended in all of data collection and analyzed for descriptive and bivariate analysis (mean age $15.77 \pm 1.07$ years old) and BMI/Age $\mathrm{z}$-score $-0.28 \pm 0.84$. Fortynine point two percent was aged from 13 to 15 years old and $50.8 \%$ was between 16 and 18 years old (Table 1). Nutrition status was divided into 2 categories, which were normal (58 respondents, 95.1\%) and overweight (3 respondents, 4.9\%). Education level was obtained; showing higher level of education $(\geq$ 9 years) was $25(41 \%)$ and $19(31 \%)$ respondents, for father and mother respectively. Furthermore, it was found that 8 respondent's father (13.1\%)

Table 1. Respondent frequency based on the age, and nutritional status

\begin{tabular}{llcc}
\hline \multicolumn{1}{c}{ Parameters } & \multicolumn{1}{c}{ Categories } & $\begin{array}{c}\text { Frequency } \\
\text { (n) }\end{array}$ & (\%) \\
\hline Age & 13-15 years old & 30 & 49.2 \\
& $16-18$ years old & 31 & 50.8 \\
Nutritional status* & Normal & 58 & 95.1 \\
& Overweight & 3 & 4.9 \\
Parental Education & & & \\
Paternal education & $<9$ years & 36 & 59 \\
& $\geq 9$ years & 25 & 41 \\
Maternal education & $<9$ years & 42 & 68.9 \\
& $\geq 9$ years & 19 & 31.1 \\
Working Status & & & \\
Father & Formal & 8 & 13.1 \\
& Informal & 53 & 86.9 \\
Mother & Working & 14 & 23 \\
& Not working & 47 & 77 \\
Income/month & $<1.5$ million IDR & 21 & 34.4 \\
& $\geq 1.5$ million IDR & 40 & 65.6 \\
Expenses/month & $<1.5$ million IDR & 32 & 52.5 \\
& $\geq 1.5$ million IDR & 29 & 47.7 \\
\hline
\end{tabular}

Note $*$ ) : Nutritional status was categorized using children's anthropometry standards for BMI/age where normal is between -2 $\mathrm{SD}$ and $+1 \mathrm{SD}$ and overweight is ranging from $+1 \mathrm{SD}$ to $+2 \mathrm{SD}$ (Indonesian Ministry of Health, 2020) working formal in the office, and 53 subject's father (86.9\%) employing informal (Table 1).

Average energy intake was $1367.4 \pm 243.1$ kcal, whereas carbohydrate consumption was $196.7 \pm 37.2 \mathrm{~g}$. In addition, average protein intake was $42.5 \pm 10.9 \mathrm{~g}$ and fat consumption was $46.4 \pm$ $13.3 \mathrm{~g}$ (Table 2). Table 4 shows the percentage of recommended dietary allowance, which revealed for energy $64.3 \pm 11.4 \%$, carbohydrate $67.4 \pm 12.8 \%$, protein $66.9 \pm 18.3 \%$, and fat $65.3 \pm 18.7 \%$.

Study were focusing on iron intake, which is one of the main factors to prevent anemia (Permaesih \& Herman, 2005). The result showed that average iron intake in this study was observed $8.11 \pm 2.94 \mathrm{mg} /$ day (ranging from 3.01 to 20.43 $\mathrm{mg} /$ day) (Table 2) and \% iron RDI was pointed out $31.18 \pm 11.32 \%$ (between 11.58 and $78.58 \%$ ) (Table 3 ). Previous study revealed a higher result, which were 18,3+30,43 mg/day (Kirana, 2011), $11.3 \pm 1.75 \mathrm{mg} /$ day (Cendani \& Murbawani, 2011), and $10.4 \pm 4.02 \mathrm{mg} /$ day (Adhisti \& Puruhita, 2011). This result might explain why Banten Province had a higher of anemia prevalence, which was more than 50\% (Prihatini et al., 2009). Therefore, to support effort to lower prevalence of reproductive women, it requires a thorough and detail planning from Government to increase iron consumption, applying a supplementation such as iron tablet (Indonesian Ministry of Health, 2014b; World Health Organization, 2001) or exploiting the food diversity for iron sources (Indonesian Ministry of Health, 2014a; World Health Organization, 2001).

Food pattern provides a description regarding frequency, and variety of food consumed. Indonesian Ministry of Health (2014a) has issued policy for society to consume foods from diverse sources of animals and plants foods as iron resources. However, as seen in Table 5, when tenhighest high-iron foods consumed was divided into

Table 2. Descriptive analysis of nutrient intake, calculated with 24 hour food recall

\begin{tabular}{lrrrc}
\hline & Mean & \multicolumn{1}{c}{ SD } & Minimum & Maximum \\
\hline Calories (kcal) & 1367.4 & 243.1 & 723.3 & 1887.7 \\
Carbohydrate (g) & 196.7 & 37.2 & 103.6 & 274.1 \\
Protein (g) & 42.5 & 10.9 & 21.5 & 86.3 \\
Fat (g) & 46.4 & 13.3 & 14.0 & 82.0 \\
Iron (mg) & 8.1 & 2.9 & 3.0 & 20.4 \\
\hline
\end{tabular}


Table 3. Descriptive analysis of Indonesian recommended dietary allowance percentage

\begin{tabular}{llccc}
\hline & Mean & SD & Minimum & Maximum \\
\hline Calories & 64.3 & 11.4 & 34.0 & 88.8 \\
Carbohydrate & 67.4 & 12.8 & 35.5 & 93.9 \\
Protein & 66.9 & 18.3 & 36.5 & 146.2 \\
Fat & 65.3 & 18.7 & 19.7 & 115.5 \\
Iron & 31.2 & 11.3 & 11.6 & 78.6 \\
\hline
\end{tabular}

frequent and infrequent (Table 4), tempeh and tofu was the two-most consumed foods by respondents, resulting $86.9 \%$ and $59 \%$, respectively. Egg became the third eaten food, which was around $54.1 \%$ respondents. Furthermore, the last food that correspondent to more than $50 \%$ frequency was instant noodles. Except above mentioned foods were calculated less than $50 \%$, which were oncom, chicken's liver, long bean, mung bean, shrimp and anchovy.

Looking at the data regarding ten-highest high-iron foods consumed, the two-most frequent iron consumed foods came from plants sources, which was tempeh and tofu. One study highlighted that there was a link between land ownership and house-hold food security (Tanziha \& Herdiana, 2009). Therefore, because of living in rural region, plants sources, which are easy to access and free, become the most frequent consumed of iron foods to fulfill the iron requirement. This source was known to have lower bioavailability compared with animal foods (Tatala et al., 1998).

One of animal iron sources, which consumed more than $50 \%$, was eggs. However, eggs only provide around $3 \mathrm{mg} / 100 \mathrm{~g}$, which is not an adequate source of iron. This pattern, revealing a higher intake of plant sources with lower amount of iron, at the end, might contribute to anemia (Collings, et al., 2013; Prihatini, et al., 2009; Tatala, et al., 1998). The low consumption of animal iron food can be fully understood because the price is higher than other types of food. Therefore, food access to consume animal iron sources is also affected due to low power of purchasing (Bindon \& Vitzthum, 2002).

Table 6 shows that parents education, both father and mother, did not influence iron consumption $(8.41 \pm 3.54$ vs $7.67 \pm 1.75$, and 8.35 \pm 3.22 vs $7.57 \pm 2.19$, respectively for $<9$ years and $\geq 9$ years, $p>0,05$ ). There was a contradictory
Table 4. Frequency of ten-highest high-iron foods consumed

\begin{tabular}{|c|c|c|c|}
\hline Foods & Category & Frequency & $(\%)$ \\
\hline \multirow[t]{2}{*}{ Oncom } & Frequent & 9 & 14.7 \\
\hline & Infrequent & 52 & 85.3 \\
\hline \multirow[t]{2}{*}{ Chicken's Liver } & Frequent & 23 & 37.7 \\
\hline & Infrequent & 38 & 62.3 \\
\hline \multirow[t]{2}{*}{ Tempeh } & Frequent & 53 & 86.9 \\
\hline & Infrequent & 8 & 13.1 \\
\hline \multirow[t]{2}{*}{ Noodles } & Frequent & 32 & 52.5 \\
\hline & Infrequent & 29 & 47.5 \\
\hline \multirow[t]{2}{*}{ Long bean } & Frequent & 24 & 39.3 \\
\hline & Infrequent & 37 & 60.7 \\
\hline \multirow[t]{2}{*}{ Chicken Egg } & Frequent & 33 & 54.1 \\
\hline & Infrequent & 28 & 45.9 \\
\hline \multirow[t]{2}{*}{ Mung Bean } & Frequent & 29 & 47.5 \\
\hline & Infrequent & 32 & 52.5 \\
\hline \multirow[t]{2}{*}{ Tofu } & Frequent & 36 & 59.0 \\
\hline & Infrequent & 25 & 41.0 \\
\hline \multirow[t]{2}{*}{ Shrimp } & Frequent & 21 & 34.4 \\
\hline & Infrequent & 40 & 65.6 \\
\hline \multirow[t]{2}{*}{ Anchovy } & Frequent & 30 & 49.2 \\
\hline & Infrequent & 31 & 50.8 \\
\hline
\end{tabular}

result between our finding and previous studies, which could establish a significant relation of parents education to iron intake (Basith, et al., 2017; Choi, et al., 2011; Farida, et al, 2014; Rahayu $\&$ Dieny, 2012). In a reviewed publication, it turns out that parents education might be a contributing factor to iron intake (Nguyen, et al., 2015), which noted that the higher education the higher prospect to have a better nutrition knowledge, resulting to present an improvement of nutrient intake quality and quantity. However, one study found similar results, which could not observe a difference between iron intake and parents education (Choi, et al., 2011).

Although almost adolescent girls in this study live with their parents, there is a phenomenon where they are more independent in choosing amount and kind of foods. For example, studies found that more than $50 \%$ adolescent girls did not have breakfast (Hermina, et al., 2009; Kalsum \& Halim, 2016). In addition, adolescent girls tend to perform a poor food pattern habit, which showed by a study in Bukit Tinggi where 60\% of adolescent girls practice that model (Santy, 2006). 
Table 5. Coefficient correlation between iron intake and ten-highest iron sources consumed

\begin{tabular}{lcc}
\hline \multicolumn{1}{c}{ Foods } & Coefficients & p-value \\
\hline Oncom & 0.07 & 0.58 \\
Chicken's Liver & -0.05 & 0.73 \\
Tempeh & -0.04 & 0.76 \\
Noodles & 0.09 & 0.51 \\
Long bean & 0.08 & 0.55 \\
Chicken Egg & -0.09 & 0.49 \\
Mung Bean & 0.05 & 0.72 \\
Tofu & 0.09 & 0.51 \\
Shrimp & -0.15 & 0.25 \\
Anchovy & 0.02 & 0.89 \\
\hline
\end{tabular}

Father's employment significantly affected iron intake, showing an consumption $8.40 \pm 2.99$ $\mathrm{mg} /$ day and $6.20 \pm 1.72 \mathrm{mg} /$ day for informal and formal working, respectively $(p<0,05)$ (Table 6). This result indicates that father's employment in informal sector allows beneficial part on choosing and determining iron intake. This research was conducted in rural areas where most of father's work was informal (87\%). Therefore, in this study, it can be hypothesized that role of fathers for choosing the quantity, type and quality of foods

Table 6. Iron intake based on family socio-economic

\begin{tabular}{|c|c|c|c|c|c|}
\hline \multirow{2}{*}{\multicolumn{2}{|c|}{$\begin{array}{l}\text { Socio-economic } \\
\text { parameters }\end{array}$}} & \multicolumn{3}{|c|}{$\begin{array}{c}\text { Iron intake (mg/ } \\
\text { day) }\end{array}$} & \multirow[t]{2}{*}{ p-value } \\
\hline & & $\mathbf{n}$ & Mean & SD & \\
\hline \multicolumn{6}{|l|}{ Education } \\
\hline \multirow{2}{*}{ Father } & $<9$ years & 36 & 8.41 & 3.54 & \multirow{2}{*}{0.730} \\
\hline & $\geq 9$ years & 25 & 7.67 & 1.75 & \\
\hline \multirow[t]{2}{*}{ Mother } & $<9$ years & 42 & 8.35 & 3.22 & \multirow{2}{*}{0.640} \\
\hline & $\geq 9$ years & 19 & 7.57 & 2.19 & \\
\hline \multicolumn{6}{|c|}{ Working status } \\
\hline \multirow[t]{2}{*}{ Father } & Formal & 8 & 6.20 & 1.72 & \multirow{2}{*}{$0.033^{*}$} \\
\hline & Informal & 53 & 8.40 & 2.99 & \\
\hline \multirow[t]{2}{*}{ Mother } & Working & 14 & 7.11 & 1.18 & \multirow{2}{*}{0.123} \\
\hline & Not working & 47 & 8.41 & 3.24 & \\
\hline \multirow[t]{2}{*}{$\begin{array}{l}\text { Family } \\
\text { income }\end{array}$} & $\begin{array}{l}<1.5 \text { million } \\
\text { IDR }\end{array}$ & 21 & 8.33 & 3.53 & \multirow{2}{*}{0.721} \\
\hline & $\begin{array}{l}\geq 1.5 \text { million } \\
\text { IDR }\end{array}$ & 40 & 7.99 & 2.63 & \\
\hline \multirow[t]{2}{*}{ Spending } & $\begin{array}{l}<1.5 \text { million } \\
\text { IDR }\end{array}$ & 32 & 8.21 & 3.06 & \multirow{2}{*}{0.828} \\
\hline & $\begin{array}{l}\geq 1.5 \text { million } \\
\text { IDR }\end{array}$ & 29 & 7.99 & 2.85 & \\
\hline
\end{tabular}

* shows a significant difference $(\mathrm{p}<0.05)$ for households will be greater due to having more available time to communicate and interact with mothers. However, in the society particularly in Indonesia, the role for choosing ingredients and foods typically is done by mothers, where they dominantly buy and cook for the whole family (Astuti, 2013; Putri \& Kusbaryanto, 2012). Interestingly, working status for mother, whether they were working or not, did not influence iron intake $7.11 \pm 1.18 \mathrm{mg} /$ day and $8.41 \pm 3.24 \mathrm{mg} /$ day, respectively for working and not working mother $(p>0,05)$ (Table 6).

This research also obtained a result showing that there was no significant difference between iron intake, family salary and spending $(p>$ $0,05)$ (Table 7). In our study, we could not find significant difference between salary income and iron intake. It is possibility due to the location of the study, which was in rural region, which mostly still have larger land for farming. In Lebak, a study found that there was a positive correlation between land ownership and house-hold food security (Tanziha \& Herdiana, 2009). This implies that the more land they owned, the greater the chance of achieving household food security. In contrast, study by Rahayu dan Dieny (2012) found a relation of family income and expenditure to iron consumption in Tangerang Selatan city. The higher family income and spending for foods, the higher iron intake. Other studies in India and The Netherland also signified the effect of family income and spending on iron intake (Bharati, et al., 2004; Hulshof, et al., 2003). All of those factors contribute to family privilege to select nutrient

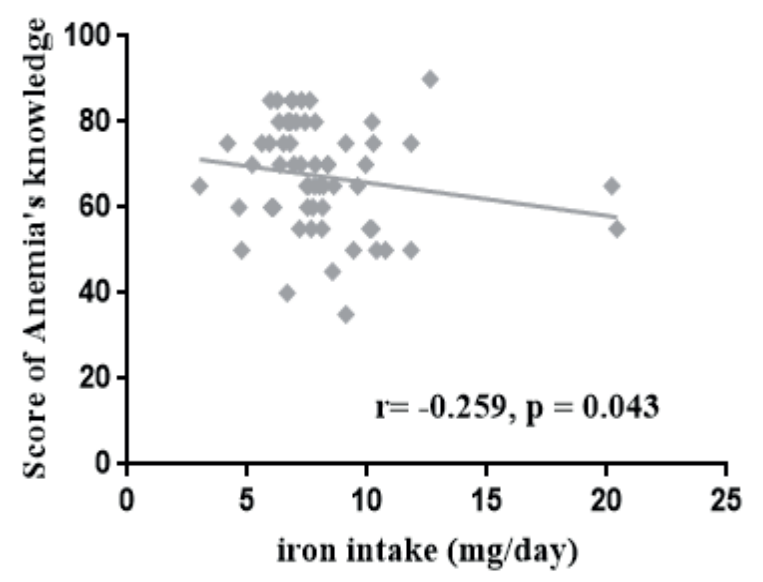

Figure 1. Correlation between score of knowledge about anemia and iron intake (mg/day) 
intake specifically on quality and quantity (Nguyen et al., 2015; World Health Organization, 2001).

Our result showed that average score of knowledge about anemia was $67.3 \pm 12.47$. Anemia knowledge were measured gained information regarding anemia specifically definition, type and caused of anemia as well as its effects on health. Studies revealed that knowledge is significantly motivated pregnant mother to consume iron supplementation tablet (Nora, 2012; Puspitaningrum \& Fratika, 2014). However, this study found that there was a negative correlation between iron intake and knowledge about anemia $(r=-0.259, p=0.043)$. Explanation of what influencing factors on iron intake might be important. Since respondents were still adolescent, it is quite-obvious that the preference of foods for their daily meals is influenced by their parents, who are choosing and providing most of the consumed foods. In addition, there is a tendency where adolescent girls aim to have an ideal body image (Denich \& Ifdil, 2015; Widianti \& Candra, 2012), which causes them to perform a diet such as no breakfast (Hermina, et al., 2009; Kalsum \& Halim, 2016; Saufika, et al., 2012). In addition, adolescent girls have irregular eating patterns (Jafar, 2012). Both reasons could contribute to reduce their nutritional intake, including macro and micro nutrients. Moreover, intervention by giving nutrition education to adolescent girls also did not affect to a better result on nutrient intake, including iron (Silalahi, et al., 2016).

\section{CONCLUSION}

Mean of iron intake in adolescent girls was around $8 \mathrm{mg} /$ day or $31 \%$ of recommended dietary intake (RDI). This study found that socioeconomic factor did not influence iron intake, except for employment status of father, which showed a higher intake when father works in informal sector compared to formal sector. Iron intake was negatively correlated with knowledge about anemia, showing a lower intake of iron for higher knowledge about anemia. Therefore, adolescent girls require to diverse the source of their iron daily intake, by choosing high-iron foods and animal sources of iron such as liver from chicken or cow, red meat, and other high sources of iron, as well as complying national program of iron supplementation, which might adequately supply iron needs.

\section{REFERENCES}

Adhisti, A.P. \& Puruhita, N.. (2011). Hubungan status antropometri dan asupan gizi dengan kadar hb dan ferritin remaja putri (Penelitian pada remaja putri pondok pesantren At-Taqwa Semarang). (Skripsi), Universitas Diponegoro, Semarang.

Astuti, A.W.W. (2013). Peran ibu rumah tangga dalam meningkatkan kesejahteraan keluarga. Universitas Negeri Semarang, Semarang.

Badan Penelitian dan Pengembangan Kesehatan RI. (2012). Survei Kesehatan Rumah Tangga (SKRT) 2012 Litbangkes (Vol. 2). Jakarta.

Basith, A., Agustina, R., \& Diani, N. (2017). Faktorfaktor yang berhubungan dengan kejadian anemia pada remaja putri. Dunia Keperawatan, 5(1), 1-10.

Bharati, P., Ghosh, R., \& Gupta, R. (2004). Socioeconomic condition and anaemia among the Mahishya population of Southern West Bengal, India. Malaysian journal of nutrition, 10(1), 23-30. Retrieved from https://pubmed. ncbi.nlm.nih.gov/22691745/

Bhargava, A., Bouis, H.E., \& Scrimshaw, N.S. (2001). Dietary intakes and socioeconomic factors are associated with the hemoglobin concentration of Bangladeshi women. The Journal of nutrition, 131(3), 758-764. doi: 10.1093/jn/131.3.758

Bindon, J.R. \& Vitzthum, V.J. (2002). Household economic strategies and nutritional anthropometry of women in American Samoa and highland Bolivia. Social science \& medicine, 54(8), 12991308. doi: 10.1016/s0277-9536(01)00097-1

Bird, K. \& Manning, C. (2002). The impact of minimum wages on employment and earnings in the informal sector. Paper presented at the th East Asian Economic Association Conference, Kuala Lumpur, November.

Cendani, C. \& Murbawani, E.A. (2011). Asupan mikronutrien, kadar hemoglobin dan kesegaran jasmani remaja putri. Media Medika Indonesiana, 45(1), 26-33. Retrieved from https://ejournal. undip.ac.id/index.php/mmi/article/view/3119

Choi, H.J., Lee, H.J., Jang, H.B., Park, J.Y., Kang, J.H., Park, K.H., \& Song, J.H. (2011). Effects of maternal education on diet, anemia, and iron deficiency in Korean school-aged children. BMC 
public health, 11(1), 870. doi: 10.1186/14712458-11-870

Collings, R., Harvey, L.J., Hooper, L., Hurst, R., Brown, T.J., Ansett, J., . . . Fairweather-Tait, S.J. (2013). The absorption of iron from whole diets: a systematic review. Clin Nutr, 98, 65-81. doi: 10.3945/ajcn.112.050609

Dahlan, M.S. (2011). Statistik untuk kedokteran dan kesehatan: Penerbit Salemba.

Denich, A.U. \& Ifdil, I. (2015). Konsep body image remaja putri. Jurnal Konseling dan Pendidikan, 3(2), 55-61. doi: 10.29210/116500

Farida, I., Widajanti, L., \& Pradigdo, S.F. (2014). Determinan kejadian anemia pada remaja putri di Kecamatan Gebog Kabupaten Kudus tahun 2006. Jurnal Gizi Indonesia (The Indonesian Journal of Nutrition), 2(1). doi: 10.14710/ jgi.2.1.

Galobardes, B., Morabia, A., \& Bernstein, M.S. (2001). Diet and socioeconomic position: does the use of different indicators matter? International journal of epidemiology, 30(2), 334-340. doi: 10.1093/ije/30.2.334

Handelman, G.J. \& Levin, N.W. (2008). Iron and anemia in human biology: a review of mechanisms. Heart Failure Reviews, 13(4), 393-404. doi: 10.1007/s10741-008-9086-x.

Hermina, H., Nofitasari, A., \& Anggorodi, R. (2009). Faktor-faktor yang mempengaruhi kebiasaan makan pagi pada remaja putri di Sekolah Menengah Pertama (SMP). Penelitian Gizi dan Makanan (The Journal of Nutrition and Food Research), 32(2). Retrieved from http:// ejournal.litbang.kemkes.go.id/index.php/pgm/ article/view/1458

Hulshof, K.F.A.M., Brussaard, J.H., Kruizinga, A.G., Telman, J., \& Löwik, M.R.H. (2003). Socio-economic status, dietary intake and $10 \mathrm{y}$ trends: the Dutch National Food Consumption Survey. European journal of clinical nutrition, 57(1), 128. doi: 10.1038/sj.ejen. 1601503

Indonesian Ministry of Health. (2013). Riset Kesehatan Dasar (RISKESDAS) 2013 Jakarta: Kementerian Kesehatan RI.

Indonesian Ministry of Health. (2014a). Pedoman Gizi Seimbang. Jakarta: Kementerian Kesehatan.

Indonesian Ministry of Health. (2014b). Peraturan Menteri Kesehatan Republik Indonesia Nomor 88 Tahun 2014 Tentang Standar Tablet Tambah Darah Bagi Wanita Usia Subur Dan Ibu Hamil. Jakarta: Kementerian Kesehatan.
Indonesian Ministry of Health. (2020). Peraturan Menteri Kesehatan Republik Indonesia Nomor 2 Tahun 2020 Tentang Standar Antropometri Anak. Jakarta: Kementerian Kesehatan RI

Jafar, N. (2012). Perilaku Gizi Seimbang pada Remaja. Fakultas Kesehatan Masyarakat Universitas Hasanuddin.

Johnson-Wimbley, T.D. \& Graham, D.Y. (2011). Diagnosis and management of iron deficiency anemia in the 21 st century. Therapeutic advances in Gastroenterology, 4(3), 177-184. doi: $10.1177 / 1756283 X 11398736$

Kalsum, U. \& Halim, R. (2016). Kebiasaan Sarapan Pagi berhubungan dengan Kejadian Anemia pada Remaja di SMA Negeri 8 Muaro Jambi. Jurnal Penelitian Universitas Jambi: Seri Sains, 18(1)

Kirana, D.P. (2011). Hubungan Asupan Zat Gizi dan Pola Menstruasi dengan kejadian anemia pada remaja putri di SMA N 2 Semarang. Diponegoro University.

Lopez, A., Cacoub, P., Macdougall, I.C., \& PeyrinBiroulet, L. (2016). Iron deficiency anaemia. The Lancet, 387(10021), 907-916.

Nguyen, P.H., Gonzalez-Casanova, I., Nguyen, H., Pham, H., Truong, T.V., Nguyen, S., . . . Ramakrishnan, U. (2015). Multicausal etiology of anemia among women of reproductive age in Vietnam. European journal of clinical nutrition, 69(1), 107.

Nora, S. (2012). Hubungan pengetahuan ibu hamil tentang anemia defisiensi besi dengan kepatuhan dalam mengkonsumsi tablet zat besi di bidan praktek swasta Cut Maryamah Tringgadeng Tahun 2012. Jurnal Kesehatan Masyarakat.

Perkins, D.H., Radelet, S., Snodgrass, D.R., Gillis, M., \& Roemer, M.. (2001). Economics of Development. W. W: Norton \& Company, Inc., New York.

Permaesih, D. \& Herman, S. (2005). Faktor-faktor yang mempengaruhi anemia pada remaja. Buletin Penelitian Kesehatan, 33 (4 Des). Retrieved from http://ejournal.litbang.depkes.go.id/index. php/BPK/article/download/219/294

Piercy, K.L., Troiano, R.P., Ballard, R.M., Carlson, S.A., Fulton, J.E., Galuska, D.A., . . . Olson, R.D. (2018). The physical activity guidelines for Americans. Jama, 320(19), 2020-2028. doi: 10.1001/jama.2018.14854

Prapitasari, E. (2013). Hubungan antara tingkat pengetahuan anemia dan sikap ibu hamil dalam mengkonsumsi tablet fe dengan kejadian anemia 
di Wilayah Kerja Puskesmas Kerjo Kabupaten Karanganyar. Universitas Muhammadiyah Surakarta, Surakarta.

Prihatini, S., Kartika, V., \& Sari, Y.D. (2009). Konsumsi daging sebagai indikator anemia pada wanita usia subur. Penelitian Gizi dan Makanan, 32(2), 112-121.

Puspitaningrum, D. \& Fratika, N.M.. (2014). Hubungan pengetahuan tentang anemia, pendidikan ibu, konsumsi tablet Fe dengan kadar hb pada ibu hamil trimester III di RB Bhakti Ibu Kota Semarang. (Skripsi), Universitas Muhammadiyah Surakarta, Surakarta.

Putri, D.F.T.P., \& Kusbaryanto. (2012). Perbedaan hubungan antara ibu bekerja dan ibu rumah tangga terhadap tumbuh kembang anak usia 2-5 tahun. Mutiara Medika: Jurnal Kedokteran dan Kesehatan, 12(3), 143-149. Retrieved from https:/journal.umy.ac.id/index.php/mm/article/ view/1032

Rahayu, S.D., \& Dieny, F.F.. (2012). Citra tubuh, pendidikan ibu, pendapatan keluarga, pengetahuan gizi, perilaku makan dan asupan zat besi pada siswi SMA. Media Medika Indonesiana, 46(3), 184-194. Retrieved from https://ejournal.undip.ac.id/index.php/mmi/ article/view/4578

Santy, R. (2006). Determinan indeks massa tubuh remaja putri di kota bukit tinggi, tahun 2006 . Kesmas: National Public Health Journal, 1(3), 134-138. doi: 10.21109/kesmas.v1i3.308

Saufika, A., Retnaningsih, A., \& Alfiasari, A. (2012). Gaya hidup dan kebiasaan makan mahasiswa. Jurnal Ilmu Keluarga dan Konsumen, 5(2), 157165. doi: 10.24156/jikk.2012.5.2.157
Silalahi, V., Aritonang, E., \& Ashar, T.. (2016). Potensi pendidikan gizi dalam meningkatkan asupan gizi pada remaja putri yang anemia di Kota Medan. Jurnal kesehatan masyarakat, 11(2), 295-301. Retrieved from https:// journal.unnes.ac.id/nju/index.php/kemas/ article/view/4113

Soraya, M.N. (2013). Hubungan Tingkat Pengetahuan tentang Anemia pada Ibu Hamil dengan Kepatuhan dalam Mengkonsumsi Tablet Besi (Fe) di Puskesmas Keling II Kabupaten Jepara Tahun 2013. (S-1 Skripsi), UIN Jakarta, Jakarta.

Tanziha, I. \& Herdiana, E.. (2009). Analisis jalur faktor-faktor yang mempengaruhi ketahanan pangan rumah tangga di Kabupaten Lebak, Propinsi Banten. Jurnal Gizi dan Pangan, 4(2), 109-115. doi: 10.25182/jgp.2009.4.2.109-115

Tatala, S., Svanberg, U., \& Mduma, B. (1998). Low dietary iron availability is a major cause of anemia: a nutrition survey in the Lindi District of Tanzania. The American journal of clinical nutrition, 68(1), 171-178. doi: 10.1093/ ajen/68.1.171

United Nations Sub-Committee on Nutrition (ACC/ SCN). (2000). Fourth Report on the World Nutrition Situation: Nutrition throughout the life cicle: United Nations Washington^ eDC. DC.

Widianti, N. \& Candra, A. (2012). Hubungan antara body image dan perilaku makan dengan status gizi remaja putri di sma theresiana semarang. Diponegoro University.

World Health Organization. (2001). Iron deficiency anaemia: assessment, prevention and control $A$ guide for programme managers. 